\title{
Toward Student Development Of A Better Understanding Of The Cash Flow Statement
}

John R. Mills, (E-mail: mills@unr.nevada.edu), University of Nevada, Reno Lynn Bible, (E-mail: lynnb@unr.edu), University of Nevada, Reno

\begin{abstract}
FASB Statement No. 95, Statement of Cash Flows has now been in existence for more than ten years (since 1988) and yet, there still has not been any consensus about how to effectively evaluate information provided from this statement. Accounting educators should be the primary personnel for disseminating the necessary information for understanding the cash flow statement as well as for providing the analytical tools for evaluating the cash flow information. Carslaw and Mills (1992) provided a preliminary study that examined the intermediate textbooks to determine what the authors were providing in terms of analytical tools for evaluating cash flow information. The study concluded that while all the textbook authors point out that the cash flow statement should be used to evaluate liquidity and financial flexibility, none provided analytical tools for evaluation. The Carslaw and Mills article then provided a series of suggested ratios that they felt might provide a foundation for analyzing cash flow information. This paper is a follow-up of the prior study. We reviewed the information in the current intermediate accounting texts that provides a basis for the evaluation of the cash flow statement. Our conclusion is that, while some authors have attempted to provide better measures of cash flow information, ten years later, there is still no common consensus among authors on providing the necessary tools for properly analyzing cash flow information.
\end{abstract}

\section{Introduction}

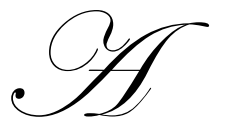

review of current intermediate accounting texts provides evidence of the additional complexities associated with deriving accrual based financial statements. The texts are full of additional detail coming from various FASB rulings used in providing financial information for annual reports. But, it appears that many of the texts are providing this information at the expense of minimizing the skills needed for analyzing these same financial statements. In 1992, all of the available intermediate texts provided a chapter that was designed to enhance a student's analytical skills by providing the student with an understanding of the ratios used to evaluate the financial position of a company. While ratios were provided for analyzing the income statement and the balance sheet, all the authors completely ignored the cash flow statement. A review of current texts finds that the analysis chapter is being put into appendixes, not included at all or spread out over the relevant chapters without a comprehensive chapter for bringing everything together. Current texts have begun to include cash flow ratios as part of the financial analysis. However, when there is analytical information, there is a wide variation of cash flow ratios presented by the authors. The authors provided 29 different cash flow ratios. There was one ratio used by three authors. For all the other ratios there were never more than two authors who had the same ratio and who agreed on its function. This lack of common cash flow ratios can present problems when students enter the workplace.

Students need to be able to develop analytical skills for the evaluation of financial statements. If they go down the CPA path, they will find that one of the first tasks that must be completed before the development of an audit plan for a company is an analytical review. The analytical review process is designed to evaluate any significant changes that have taken place in a company's financial statements. Obviously, the statement of cash flows is considered one of the important statements along with the balance sheet and the income statement and yet little is being done on analyzing this particular statement.

Readers with comments or questions are encouraged to contact the authors via email. 
Many audit plans still ignore any analytical reviews of the statement of cash flow (Mills and Yamamura 1998). The current authors believe that these analytical skills need to be developed while students are still in the classrooms and that the intermediate accounting classes should represent the primary exposure to these tools. This said, faculty must either find a text that provides the foundation tools for analyzing financial statements or provide additional supplements such as articles that discuss the needs for better cash flow analysis and suggest relevant ratios suitable for analysis.

This paper provides a review of the current texts to determine what is included on cash flow analysis and to find some common elements among these texts for cash flow analysis. It also provides a literature review that suggests what ratios are being used in industry and should be incorporated into any classroom discussions on cash flow analysis.

\section{Text Book Analysis}

In 1992, texts typically included two chapters that discussed the statement of cash flow (Carslaw and Mills 1992). The first chapter combined the balance sheet and statement of cash flow. This chapter provided a broad overview of the contents of the statement and a historical background of its development. The chapter reviewed the foundation and theory for what transactions fit into which components of the statement of cash flow (operating, investing, and financing). It also tried to get across to the reader that this statement was a very important statement for analyzing liquidity and flexibility. Unfortunately, students were left to wonder how they could evaluate cash flow liquidity and flexibility because none of the texts provided the tools for doing this.

The second chapter was a chapter devoted to the creation of the statement of cash flow as derived from information obtained from the balance sheet and the income statement. It provided the foundation for preparing the statement of cash flows but once again lacked any information for evaluating the results obtained from the statement of cash flow. Furthermore, while all the texts in 1992 provided a ratio analysis chapter (usually the last chapter in the book), not a single text provided any cash flow ratios.

Currently, intermediate accounting texts have taken several approaches toward providing analytical skills for evaluating financial statements. Typically, there is an introductory chapter for the Income Statement followed by a chapter for the Balance Sheet and the Cash Flow Statement. These two chapters describe the purpose and function of these statements (in future discussion, we will refer to this chapter as the theory chapter). Later in the text, is a second chapter devoted to the statement of cash flow. This chapter basically provides the tools to create the statement of cash flow using information from the balance sheet and income statement (in future discussion, we will refer to this chapter as the preparation chapter). In terms of financial statement analysis, authors have taken several approaches. The traditional approach has been to have a separate chapter that incorporates all ratios used to evaluate all the financial statements. A secondary approach is to incorporate the ratios into the chapters where a specific topic is covered. For example, the inventory turnover ratio would be covered in the inventory chapter. An alternative approach is to incorporate the ratios into the two introductory chapters presenting the financial statements.

The original Carslaw and Mills study included the review of seven intermediate texts. Four of these texts (Chasteen, Kieso, Nikolai, and Skousen) are still available in revised editions. There are three additional intermediate texts that are replacing the three texts from the original study (see Table 1$)^{1}$. Six of the seven texts currently provide some cash flow ratios. One, Chasteen, Flaherty, and O'Connor, still does not provide any relevant cash flow ratios. What is surprising is the lack of any consensus between the remaining authors. These six authors came up with a total of 29 different cash flow ratios!

\footnotetext{
${ }^{1}$ Mosich, Intermediate Accounting, McGraw Hill Revised 6th ed. 1989; Welsch and Zlatkavich, Intermediate Accounting, Irwin 8th ed. 1989; and Williams, Stanga, and Holder, Intermediate Accounting, Harcourt Brace Jovanovich 3rd ed. 1989 are no longer in publication.
} 
Table 1

\section{Textbooks Surveyed}

\section{Textbook}

1. Chasteen, Flaherty, and O'Connor, Intermediate Accounting, Irwin McGraw-Hill $6^{\text {th }}$ ed. 1998.

2. Dyckman, Davis, and Dukes, Intermediate Accounting, Irwin McGraw-Hill $5^{\text {th }}$ ed. 2001.

3. Hartman, Harper, Knoblett, and Reckers, Intermediate Accounting, South-Western $3^{\text {rd }}$ ed. 2000.

4. Kieso, Weygandt, and Warfield, Intermediate Accounting, John Wiley \& Sons $10^{\text {th }}$ ed. 2001.

5. Nikolai and Bazley, Intermediate Accounting, South-Western $8^{\text {th }}$ ed. 2000.

6. Skousen, Stice, and Stice, Intermediate Accounting, South-Western $14^{\text {th }}$ ed. 2000.

7. Spiceland and Sepe, Intermediate Accounting, Irwin McGraw-Hill 1998.

Table 2 provides the format for the seven textbooks surveyed in this study. Of these seven, only two, Nikolai and Spiceland, have continued to use the 1992 format of a theory chapter, a preparation chapter and an analysis chapter. Two others, Dyckman and Kieso, have two chapters that cover the statement of cash flow but do not have a separate analysis chapter. Nikolai as well as Spiceland combine their statement of cash flow theory chapter with the income statement while two other authors, Dyckman and Kieso, combine their statement of cash flow theory chapter with the balance sheet. Chasteen provides two statement of cash flow chapters but they both combine the theory and preparation. The difference is that the later chapter uses a major company as an example for the preparation. Two authors, Hartman and Skousen, provide only one statement of cash flow chapter by combining the theory and preparation objectives. Only three authors, Nikolai, Skousen, and Spiceland, currently provide a ratio analysis chapter. Two others, Kieso and Hartman, incorporate the ratios into the chapter topic. As can be seen, there is no consensus on format.

Table 2

Format of Cash Flow Chapters by Textbook

\begin{tabular}{|c|c|c|c|c|c|c|c|}
\hline $\begin{array}{l}\text { Authors (first author on- } \\
\text { ly) }\end{array}$ & Chasteen & Dyckman & Hartman & Kieso & Nikolai & Skousen & Spiceland \\
\hline Theory Chapter & $\mathrm{Y}$ & $\mathrm{Y}$ & & $\mathrm{Y}$ & $\mathrm{Y}$ & & $\bar{Y}$ \\
\hline Combined with $\mathrm{B} / \mathrm{S}$ & & $\mathrm{Y}$ & & $\mathrm{Y}$ & & & \\
\hline Combined with I/S & & & & & $\mathrm{Y}$ & & $\mathrm{Y}$ \\
\hline Separate SOCF Chapter & $\mathrm{Y}$ & & $\bar{Y}$ & & & $\mathrm{Y}$ & \\
\hline With Cash Flow Ratios & & $\mathrm{Y}$ & & $\mathrm{Y}$ & & $\mathrm{Y}$ & $\mathrm{Y}$ \\
\hline Preparation Chapter & $\mathrm{Y}$ & $\mathrm{Y}$ & & $\mathrm{Y}$ & $\mathrm{Y}$ & & $\mathrm{Y}$ \\
\hline Does not have & & & $\mathrm{Y}$ & & & & \\
\hline With Cash Flow Ratios & & $\mathrm{Y}$ & & & & & \\
\hline Ratio Analysis Chapter & & & & & $\mathrm{Y}$ & $\mathrm{Y}$ & $\mathrm{Y}^{2}$ \\
\hline With Ratio by Topic & & & $\mathrm{Y}$ & $\mathrm{Y}$ & & & \\
\hline With Cash Flow Ratios & & & & $\bar{Y}$ & $\mathrm{Y}$ & $\mathrm{Y}$ & \\
\hline
\end{tabular}

\footnotetext{
${ }^{2}$ Spiceland separates the financial statement analysis into two chapters.
} 
Table 3 presents the placement of the ratios by textbook and the number of ratios in each chapter. As can be seen, the majority of the authors have presented a limited number of cash flow ratios. Appendix 1 provides the types of cash flow ratios presented by each of the authors. Table 3 shows that Hartman presents 14 different cash flow ratios while Spiceland presents 11 ratios. Yet, Appendix 1 shows that there are only 5 ratios that are presented by both authors. The appendix also shows that there is no consensus between any of the authors in terms of common ratios. None of these ratios had a majority of authors providing it in their texts. Only one ratio (CFO + interest + taxes/ cash interest payment) was presented by three authors; 2 or less authors provided all the others.

Table 3

Placement and Number of Ratios Presented

\begin{tabular}{|l|c|c|c|c|}
\hline $\begin{array}{l}\text { Authors } \\
\text { (First author only) }\end{array}$ & $\begin{array}{l}\text { Number of Ratios in } \\
\text { Theory Chapter }\end{array}$ & $\begin{array}{l}\text { Number of Ratios in } \\
\text { Preparation Chap- } \\
\text { ter }\end{array}$ & $\begin{array}{l}\text { Number of Ratios in } \\
\text { Financial Statement } \\
\text { Analysis Chapter }\end{array}$ & $\begin{array}{l}\text { Total Number of } \\
\text { Ratios Presented }\end{array}$ \\
\hline Chasteen & 0 & 0 & 0 & 0 \\
Dyckman & 2 & 1 & N/A & 3 \\
Hartman & N/A & 14 & 2 & 14 \\
Kieso & 3 & 0 & 4 & 3 \\
Nikolai & 0 & 0 & 1 & 4 \\
Skousen & N/A & 3 & 0 & 3 \\
Spiceland & 0 & 11 & 11 \\
\hline
\end{tabular}

Chasteen, Flaherty and O'Connor (1998) presents a combined theory and preparation chapter but then also include a revisited statement of cash flow chapter with additional disclosure topics. The second chapter provides an actual real world company (General Electric) to prepare the statement of cash flow. While the authors do not provide a separate analysis chapter, their balance sheet chapter includes an appendix on ratios for financial statement analysis. Chasteen et al. (1998) do not provide cash flow ratios but do stress the importance of using the statement to provide answers to questions not readily available from the income statement and balance sheet. They discuss cash flow analysis in terms of the sources of cash inflows and outflows in terms of activities. For example, they state that " $(t)$ he major uses of cash resources were additions to property, plant, and equipment; payment of nonoperating debt; purchase of treasury stock; and payment of dividends....Furthermore, GE's acquisition of property, plant, and equipment indicate that management expects increased demand for the company's goods and services, which suggests even greater cash inflows from operations in the future." (Chasteen et al. 1998 p.301)

Dyckman, Davis, and Dukes (2001) introduce the cash flow statement with the balance sheet. This chapter includes cash flow ratios as part of its ratio analysis. A second preparation chapter is also presented. The two ratios provided in the ratio analysis section include the $\mathrm{CFO}$ /current liabilities ratio, categorized with the activity ratios and the cash flows per share ratio (CFO/common shares outstanding), categorized with the equity position/coverage ratios. Dyckman et al. (2001) discusses free cash flow (FCF) at the end of the preparation chapter. The authors do discuss the usefulness of the cash flow statement in both the theory and the preparation chapters. They stress that it is "... an indispensable complement to the balance sheet." They also emphasis that " $(t)$ he statement of cash flows is not useful in isolation." (Dyckman et al. 2001 p. 192)

Hartman, Harper, Knoblett, and Reckers (2000) provide a single combined theory and preparation chapter. They do not provide a separate chapter on ratio analysis but integrate ratio analysis into most of the individual chapters. For example, return on assets and asset turnover are presented in the analysis of the property, plant and equipment chapter. The statement of cash flow chapter presents fourteen ratios divided into two categories, adequacy ratios and performance and quality ratios (See Appendix 1). Each ratio is discussed in terms of its purpose. For example " $(t)$ he capital acquisition ratio discloses whether COCF is adequate to fund current capital acquisitions. If not, other sources of financing must be found." (Hartman et al. 2000 p. 295) The authors also note "(w)hile a variety of cash flow ratios exist, there is no standard quantitative and objective method used for comparing various ratios and measures." (Hartman et al. 2000 p. 298) 
Kieso, Weygandt, and Warfield (2001) have two statement of cash flow chapters. Their theory chapter is presented with the balance sheet. The authors integrate relevant ratios into the individual chapters. The balance sheet and cash flow theory chapter discusses two cash flow ratios and free cash flow along with relevant balance sheet ratios. The cash flow ratios include the current cash debt coverage ratio (CFO/average current liabilities) and the cash debt coverage ratio (CFO/average total liabilities). Further discussion is presented on free cash flow. This chapter also includes an appendix with a series of ratios including two cash flow ratios that provides little in terms of ratio analysis discussion. The preparation chapter also lacks any financial statement analysis. An appendix on basic financial statement analysis is included in the chapter on full disclosure.

Nikolai and Bazley (2000) have their theory cash flow chapter with the income statement and also have a preparation chapter. Ratio analysis is included in a separate chapter titled Additional Aspects of Financial Reporting and Financial Analysis. The authors discuss four cash flow ratios as a separate category in the ratio analysis chapter, the $\mathrm{CFO} /$ sales ratio, the $\mathrm{CFO} /$ net income ratio, the cash flow per share ratio (CFO/average common stock outstanding), and $\mathrm{CFO} /$ debt maturing next year ratio. They note that "(c)ash flow ratios assist a user in understanding relationships and trends among a company's cash flows." (Nikolai and Bazley 2000 p. 197) However they state that the ratios are not computed in their analysis of Cooper Company "...because they are not generally accepted..." (Nikolai and Bazley 2000 p. 197) The cash flow ratios are not presented or discussed in either of the cash flow chapters.

Skousen, Stice and Stice (2000) have one separate chapter that deals with the statement of cash flow. They also provide an analysis of financial statements chapter. The authors provide a good discussion of cash flow ratios in the cash flow preparation chapter. The provided ratios include the CFO/net income ratio, the cash times interest earned ratio (CFO plus cash paid for interest and taxes/cash interest payments), and the cash flow adequacy ratio. It's interesting to note that the authors themselves do not provide a consistent calculation of the cash flow adequacy ratio. Within the statement of cash flows chapter they calculate the cash flow ratio as $\mathrm{CFO}$ / cash paid for capital expenditures plus cash paid for acquisitions. However, in the analysis of financial statements chapter the cash flow adequacy ratio is calculated as CFO/long-term assets purchases plus long-term debt repayments plus dividends paid. The authors use Circle K's cash flow statement to illustrate the computation of the ratios and provide an explanation for the results. Yet, in the Analysis of Financial Statements chapter, they only include discussion of the cash flow adequacy ratio. Skousen et al. (2000) state that "....more and more emphasis is now placed on cash flows and the relationships of data reported on the cash flow statement in conjunction with the income statement and the balance sheet." (Skousen et al. 2000 p. 255)

Spiceland and Sepe (1998) also have two cash flow chapters. The theory chapter is combined with the income statement and then they have a preparation chapter. Ratio analysis is found in two chapters, the Income Measurement and Profitability Analysis chapter and the Balance Sheet and Financial Disclosures chapter. Neither of these chapters includes any ratios associated with the cash flow statement. The authors present 11 cash flow ratios in their preparation chapter (see Appendix 1) but limit any interpretation of these ratios. The ratios are categorized in a table as either performance ratios or sufficiency ratios with a brief one-sentence explanation for each ratio. No other discussion of the ratios' purpose is provided other than a statement that "(s)ome cash flow ratios are derived by simply substituting cash flow from operations (CFFO) from the statement of cash flows in place of net income..." (Spiceland and Sepe 1998 p. 982).

\section{Relevance of Cash Flow Analysis}

While empirical research studies are mixed in terms of the informational content of cash flow data, analysts and bankers have incorporated cash flow ratios in their analysis for many years. A study by Gibson (1983) indicated the relative importance of cash flow information in the loan assessment process long before FASB 95 was a required statement. The study asked commercial loan officers to rank 59 different ratios in order of importance in their loan processing decisions. The top ten ratios included: cash flow/current maturities of long-term debt (ranked \#3) and cash flow/total debt (ranked \#9). These cash ratios also appeared as part of the officers' ongoing monitoring process. Reporting of cash flow/current maturities of long-term debt was included in $60 \%$ of all loan agreements while cash flow/total debt was included in $36 \%$ of all loans. In the same year Fraser (1983) argued that cash generat- 
ed from operations should receive more emphasis when doing financial analysis and that any liquidity ratio should measure the ability of the firm to generate cash to meet its cash needs. He therefore advocated that analysts examine cash flow from operations and liquid cash assets. These amounts provide the potential cash flows necessary to meet current liabilities.

The studies by Gibson (1983) and Fraser (1983) support the explanatory capabilities of the statement of cash flow in relation to the other financial statements. These studies argue that the cash flow statement can provide information with greater reliability. They suggest that the statement of cash flow should be considered essential to any evaluation of financial information.

The statement of cash flow also provides key information relating to liquidity, solvency, and financial flexibility. While the balance sheet does provide a company's existing cash and current asset position, Kieso and Weygandt (1995), among others (see for example McConville 1996; Giacomino and Mielke 1993; White et al. 1998; and Rujoub et al. 1995), holds that using only the balance sheet to ascertain liquidity does not provide sufficient information about a company's ability to meet current obligations.

The use of cash flow analysis has been cited in the literature in several industries. An article in Oil and Gas Journal by Johnston and Zipprich (1992) explains how different definitions of cash flow (also referred to as discretionary cash flow) can lead to confusion and misunderstanding. Fitch Investment Service developed the cash flow adequacy ratio to measure the corporate credit of chemical companies (Plishner 1994). In addition, analysts from the health care industry stress the value of cash flow ratios to help assess the viability of hospitals (Prince 1998).

Lenders have developed various cash flow ratios for use in making lending decisions. They have redefined traditional ratios as well as developed new ratios. But, unlike the traditional balance sheet ratios that have evolved over many years, these cash flow ratios have not as yet become common practice nor have they reached a common consensus on the definition of each ratio and what is included in the ratio. A search of the literature on cash flow ratios found a wide variety of definitions being used and a constant refining of these definitions. See for example the changing views of this author on various cash flow ratios (Mills, Bible, and Mason 2002; Bible and Mills 2001; Mills 2000; Mills and Yamamura 1998; and Carslaw and Mills 1992, 1991a, 1991b). No studies have been done that validate a specific ratio as being a good predictor of business failures.

While there is still no general consensus on suggested cash flow ratios or the definition of cash flow ratios, there are variations of several cash flow ratios that seem to be commonly used. When defining liquidity, analysts and creditors seem to like some variation of the CFO to CL. When looking at solvency, there is a tendency to go with the CFO to LTD. Quality of cash flows appears to be best represented by the CFO to Net Income and by Free Cash Flow (FCF). Free cash flow has become one of the most common indicators provided by analysts, creditors, and companies but of course, there is a very wide variation of what is included in free cash flow (Mills, Bible, and Mason 2002).

\section{Are Texts Providing Relevant Ratios?}

Appendix 1 provides a listing of all the cash flow ratios appearing in the intermediate texts. All the texts acknowledge that the statement of cash flows was developed to provide the ability to assess the liquidity and longterm solvency of a company. Many studies have shown that the CFO to current liabilities ratio is used extensively in industry analysis as a liquidity ratio. Yet only two authors, Dyckman and Kieso, include this ratio in their set of ratios, and only Kieso recognizes it as a liquidity ratio. No author includes the cash flow to current maturities of longterm debt ratio that Gibson (1983) found was one of the primary ratios used both for loan approval decisions and loan monitoring.

There is also a lack of acknowledgement of the role of cash flow ratios for analyzing solvency. Again, Kieso presents their coverage ratios as a measure of solvency. Spiceland, for example, in their risk (ratio) analysis chapter say that ratios are used to investigate a company's liquidity and long term solvency. The risk analysis chapter ratios are defined as liquidity ratios and financing ratios. But they do not develop their cash flow ratios using the 
same liquidity and solvency format. They classify their cash flow ratios as performance ratios and sufficiency ratios without any explanation. The other texts seem to have taken a similar approach. Industry analysts tend to go with the CFO to LTD as the major solvency ratio (See Gibson 1983). Only Hartman includes this ratio although Spiceland presents the ratio of CFO to payment of long-term debt and two others used CFO to average total liabilities. But, there is a substantial difference between these three ratios!

Another solvency ratio used by industry is the cash flow adequacy ratio developed by Fitch Investment Services (Plishner 1994). The Fitch cash flow adequacy ratio is based on the average of net free cash flow during the preceding three years divided by the average debt maturing during the upcoming five years. This gives a perspective on future cash flows that are necessary to meet expected future commitments and solvency. Both Hartman and Skousen provide the cash flow adequacy ratio but it is substantially different from the Fitch ratio. All other authors ignore this solvency ratio.

No author acknowledged quality ratios although four provided some form of these ratios. The Nikolai and the Skousen texts presented the CFO to net income as a cash flow ratio. The Hartman and the Spiceland texts used a similar ratio but used operating income in place of net income. Only the Dyckman and the Kieso texts presented the concept of free cash flow.

\section{Conclusion}

A study by Carslaw and Mills (1992) found a complete lack of attention to the analysis of the cash flow statement in the intermediate accounting texts. Ten years later, a new study shows that, while more intermediate accounting text authors have incorporated cash flow analysis into their texts, there still is no basic foundation for the development of cash flow analysis. Few authors are developing their cash flow ratios based on the concept of measuring liquidity and financial solvency. They have also appeared to ignore those ratios currently being used by the financial analysts and others in practice. The textbooks classified the ratios by purpose. However, there was little consensus on the purpose or terminology used for the categories. There was even less consensus on actual ratios or the computation of the ratios

While textbooks introduce cash flow ratios as a basis for financial statement analysis, most fail to provide adequate explanations on how to interpret the ratios. Some even failed to incorporate the cash flow ratios within the financial analysis process. Some even go as far as providing cash flow ratios with no discussion, leaving it to the instructor to emphasis their importance or to the student to decipher it. Spiceland and Sepe provide the best summary of the problems associated with cash flow ratio analysis.

"Cash flow ratios have received limited acceptance to date due, in large part, to the long tradition of accrual-based ratios coupled with the relatively brief time that all companies have published statements of cash flows. A lack of consensus on cash flow ratios by which to make comparisons also has slowed their acceptance. Nevertheless, cash flow ratios offer insight in the evaluation of a company's profitability and financial strength." (Spiceland and Sepe 1998)

Cash flow ratios need to be incorporated into any financial analysis process. Textbook authors have a responsibility to provide instructors and students with the tools necessary to achieve this. The lack on emphasis and consensus on cash flow ratios needs to be corrected so that future accounts have the necessary analytical skills for proper financial statement analysis. This includes analysis of the cash flow statement. 


\section{References}

1. Bible, Lynn, and John Mills. 2001. "Incorporating Cash Flow Analysis with Traditional Analysis for Evaluating Casino Financial Stability", International Journal of Gambling Studies (August).

2. Carslaw, Charles, and John Mills. 1992. "Cash Flow Analysis in Intermediate Accounting Textbooks", The Accounting Educator's Journal (Spring).

3. Carslaw, Charles, and John Mills. 1991a. "Cash Flow Ratios for the Oil and Gas Industry", Oil and Gas Quarterly (June).

4. Carslaw, Charles, and John Mills. 1991b. "Developing Ratios for Effective Analysis of the Cash Flow Statement", Journal of Accountancy (November).

5. Chasteen, Lenny G., Richard E. Flaherty, and Melvin C. O'Connor. 1998. Intermediate Accounting. $6^{\text {th }}$ Ed. New York: Irwin McGraw-Hill.

6. Dyckman, Thomas R., Charles J. Davis, and Roland E. Dukes. 2001. Intermediate Accounting. 5th Ed. New York: Irwin McGraw-Hill.

7. Fraser, L. 1983. "Cash Flow From Operations and Liquidity Analysis: A New Financial Ratio for Commercial Bank Lending Decisions", The Journal of Commercial Bank Lending 66: 3.

8. Gibson, C. 1983. "Financial Ratios as Perceived by Commercial Loan Officers", Akron Business and Economic Review (Summer).

9. Giacomino, Don E., and David E. Mielke. 1993. "Cash Flows: Another Approach to Ratio Analysis", Journal of Accountancy (March).

10. Hartman, Bart P., Robert M. Harper, James A. Knoblett, and Philip M. Reckers. 2000. Intermediate Accounting. 3rd Ed. Cincinnati, Ohio: South-Western.

11. Johnston, Daniel, and David C. Zipprich. 1992. "Definitions Clarity Cash Flow Analysis", Oil \& Gas Journal April 27.

12. Kieso, Donald E., and Jerry J. Weygandt. 2001. Intermediate Accounting. 10th Ed. New York: John Wiley \& Sons, Inc.

13. McConville, Daniel. 1996. "Cash Flow Ratios Gains Respect as Useful Tool for Credit Rating”, Corporate Cash flow Magazine (January).

14. Mills, John R., Lynn Bible, and Richard Mason. 2002. “Are You Sure It's Really Free Cash Flow?”, CPA Journal (January)

15. Mills, John R., and Jeanne Yamamura. 1998. "The Power of Cash Flow Ratios", Journal of Accountancy (March).

16. Nikolai, Loren A., and John D. Bazley. 2000. Intermediate Accounting. 8th Ed. Cincinnati, Ohio: SouthWestern.

17. Plishner, Emily S. 1994. New Credit Yardstick: "Cash Flow, Maturing Debt", Chemical Week (January 19).

18. Prince, Thomas R. 1998. "Strategic Assessment of Hospitals and Health Systems: A Financial Analyst's Perspective", Commercial Lending Review 13 (Summer): 11-21.

19. Rujoub, Mohamed A., Doris M. Cook, and Leon E. Hay. 1995. "Using Cash Flow Ratios to Predict Business Failures", Journal of Managerial Issues 7 (Spring): 75-91.

20. Skousen, K. Fred, Earl K. Stice, and James D. Stice. 2000. Intermediate Accounting. 14th Ed. Cincinnati, Ohio: South-Western.

21. Spiceland, J. David, and James F. Sepe. 1998. Intermediate Accounting. New York: Irwin McGraw-Hill.

22. White, G., A. Sondhi, and D. Fried. 1998. The Analysis and Use of Financial Statements. New York: John Wiley \& Sons, Inc. 


\section{Appendix 1}

Cash Flow Ratios Presented Within the Surveyed Textbooks

\begin{tabular}{|c|c|c|c|c|c|c|c|}
\hline Authors (first author only) & Chasteen & Dyckman & Hartman & Kieso & Nikolai & Skousen & Spiceland \\
\hline 1. $\mathrm{CFO} /$ Current Liabilities ${ }^{\mathrm{A}}$ & & $Y$ & & $Y$ & & & \\
\hline 2. CFO/Debt Maturing Next & & & & & Y & & \\
\hline $\begin{array}{l}\text { Year } \\
\text { SEO/Current } A \text { cauicition }\end{array}$ & & & & & & & \\
\hline $\begin{array}{l}\text { 3. CFO/ Current Acquisition of } \\
\text { PP\&E }\end{array}$ & & & $\mathrm{Y}$ & & & & $\mathrm{Y}$ \\
\hline 4. $\mathrm{CFO} / \mathrm{Net}$ Sales & & & & & $\mathrm{Y}$ & & $\mathrm{Y}$ \\
\hline $\begin{array}{l}\text { 5. CFO before Interest \& Tax- } \\
\text { es/Average Total Assets }\end{array}$ & & & $\mathrm{Y}$ & & & & \\
\hline 6. CFO/Average Total Assets & & & & $\mathrm{Y}$ & & & $\mathrm{Y}$ \\
\hline 7. CFO/Shareholder's Equity & & & & & & & $\mathrm{Y}$ \\
\hline $\begin{array}{l}\text { 8. Cash Acquisition of Long- } \\
\text { term Assets/Depreciation \& } \\
\text { Amortization }\end{array}$ & & & $\mathrm{Y}$ & & & & \\
\hline $\begin{array}{l}\text { 9. } \mathrm{CFO} / \text { Payment of Long-term } \\
\text { Debt }\end{array}$ & & & & & & & Y \\
\hline $\begin{array}{l}\text { 10. CFO/Cash Paid for Investing } \\
\text { \& Financing Activities }\end{array}$ & & & & & & & $\mathrm{Y}$ \\
\hline $\begin{array}{l}\text { 11. CFO/Average Total Liabili- } \\
\text { ties }^{\mathrm{B}}\end{array}$ & & & & $\mathrm{Y}$ & & & $\mathrm{Y}$ \\
\hline $\begin{array}{l}\text { 12. } \mathrm{CFO} / \text { Common Stock Out- } \\
\text { standing at Year-end }^{\mathrm{C}}\end{array}$ & & $\mathrm{Y}$ & & & $\mathrm{Y}$ & & \\
\hline $\begin{array}{l}\text { 13. CFO - Preferred Stock Divi- } \\
\text { dends/Weighted Average } \\
\text { Common Shares }\end{array}$ & & & $\mathrm{Y}$ & & & & $\mathrm{Y}$ \\
\hline 14. CFO/Cash Dividends Paid ${ }^{\mathrm{D}}$ & & & $\mathrm{Y}$ & & & & $\mathrm{Y}$ \\
\hline $\begin{array}{l}\text { 15. CFO - Preferred Stock Divi- } \\
\text { dends/Average Shareholder's } \\
\text { Equity }\end{array}$ & & & $\mathrm{Y}$ & & & & \\
\hline $\begin{array}{l}\text { 16. CFO + Interest + Taxes/Cash } \\
\text { Interest Payments }\end{array}$ & & & $\mathrm{Y}$ & & & $\mathrm{Y}$ & $\mathrm{Y}$ \\
\hline $\begin{array}{l}\text { 17. CFO/Dividends + Long-term } \\
\text { Assets + Long-term Debt }\end{array}$ & & & $\mathrm{Y}$ & & & $\mathrm{Y}$ & \\
\hline $\begin{array}{l}\text { Assets + Long-term Debt } \\
\text { 18. CFO/ Long-term Debt }\end{array}$ & & & $\mathrm{Y}$ & & & & \\
\hline 19. CFO/Net Income & & & & & $\mathrm{Y}$ & $\mathrm{Y}$ & \\
\hline 20. CFO/Operating Income & & & $\mathrm{Y}$ & & & & $\mathrm{Y}$ \\
\hline $\begin{array}{l}\text { 21. Cash Flow from Investing/ } \\
\text { Cash Flow from Financing }\end{array}$ & & & $\mathrm{Y}$ & & & & \\
\hline 22. Cash from Sales/Sales & & & $\mathrm{Y}$ & & & & \\
\hline $\begin{array}{l}\text { 24. CFO before Interest \& Tax- } \\
\text { es/Income before Interest, } \\
\text { Taxes \& Depreciation }\end{array}$ & & & $\mathrm{Y}$ & & & & \\
\hline 25. Free Cash Flow ${ }^{\mathrm{E}}$ & & $\mathrm{Y}$ & & $\mathrm{Y}$ & & & \\
\hline
\end{tabular}

${ }^{\text {A }}$ Kieso et al. (2000) uses Average Current Liabilities in the denominator.

B Spiceland and Sepe (1998) use Total Liabilities in the numerator and CFO in the denominator.

C Nikolai and Bazley (2000) use Average Common Stock Outstanding in the denominator.

${ }^{D}$ Hartman et al. (2000) also uses Dividends in the numerator and CFO in the denominator.

${ }^{\text {E }}$ Dyckman et al. (2001) calculate FCF as Operating Cash Receipts less Operating Expenses less Capital Expenditures less Debt Service; Kieso et al. (2000) calculate FCF as CFO less Capital Expenditures less Cash Dividends. 
Notes 